\title{
RESPONSE OF TWO WHEAT VARIETIES TO BIOFERTILIZATION AND ORGANIC AGRICULTURE SYSTEM ON YIELD AND INFESTATION WITH Rhizopertha dominica DURING STORAGE \\ Nour El-Din ,M. ${ }^{1}$ and Abeer A. Salem ${ }^{2}$ \\ 1 Soil, Water and Environmental Research Institute, ARC, Egypt \\ 2 Plant Protection Research Institute, ARC, Egypt
}

\section{ABSTRACT}

Two trials of winter seasons 2013 and 2014 were conducted in Lizemeter of Bacteriology Laboratory, Sakha Agricultural Research Station to investigate the potential effects of biofertilization and organic agriculture systems (had no mineral fertilizers nor chemical pesticides)compared to chemical fertilization on wheat grains yield (Egypt1 and Seds12 varieties) and susceptibility of the produced grains to infestation with Rhizopertha dominica post storage. Seds 12 wheat variety positively responded to both organic agriculture, and bioinoculation treatments whereas grains yield significantly increased through both seasons compared to NPK fertilization (traditional control), but grain index did not exhibit any response. On the other hand, grain yield and grain index of Egypt 1 were not significantly affected. In respect to infestation with $R$. dominica during storage, according to the studied parameters i.e. mean number of adults emerged, mean developmental period (life cycle) and grain weight loss, Egypt1 variety negatively affected with significant values due to biofertilization treatment compared to NPK fertilization (control), while there were significant variations in case of organic agriculture treatment. On contrast, the grains of Seds12 variety exhibited significant decreases in mean adults emerged, grain weight loss and had the longest life cycle resultant biofertilization and organic agriculture treatments. So, it is considered moderate tolerant to $R$. dominica post harvest compared to traditional control

\section{INTRODUCTION}

Wheat plant (Triticum aestivum L.) is the world major source of calories and protein. It constitutes more than $50 \%$ of the human daily food in the developing countries and not less than $20 \%$ of the daily food for human, in the well developed countries. Chemical fertilizer resulted some ecological problems and destructive side effects on the environment. Organic and biofertilizers can help in solving the problem of feeding arising from increasing of global population, at the time the agriculture facing various environmental stresses (Bato and Sanchez, 1972).

Biofertilizers have paramount significance in integrated nutrient management system to sustain agriculture productivity and healthy environment (Adesemoye and Kloepper, 2009). Moreover, biofertilizers are not only activate nutrients acquisition but also increase growth and production yield level, through production of growth regulators, such as auxin, cytokinine and gibberellins ... etc. (El-Kased et al., 1996). The role and importance of 
biofertilizers in sustainable crop production has been reviewed by several authors (Biswase et al., 1985; Katyal et al., 1994; Wani and Lee, 1995). In addition, biofertilizers technology is practiced for increasing agriculture production to limit the use of chemical fertilizers and pollution of the environment through seed inoculation with different types of microorganisms (Abd El-Ghany, 1994). It's generally accepted that, from 5 to $15 \%$ of the total dry weight of all cereals are lost after harvest, so there is thus, a continuous need to protect the stored products against deterioration, especially loss of quality and weight resulting from infestation of stored product pests during storage. In the same context the relationship between insect infestation and chemical composition of grains was investigated by many authors, (Koura et al., 1971;; El-Banby et al., 1985; Warchalewski et al., 1993 and Irshad et al., 1988). Therefore, the present investigation was designed to study the effect of different fertilizers i.e. traditional control (100\% NPK), biofertilization and organic agriculture treatments on grain yield of Seds12 and Egypt1 wheat varieties. The work also involved studying the degree of infestation of the produced wheat varieties by one of the main stored product pests Rhizopertha dominica during storage.

Materials:

\section{MATERIALS AND METHODS}

Microbial media:

Medium of Azotobacter:

Vancura and Mucura (1960) it is composed of sucrose, $30 \mathrm{~g}$; $\mathrm{K}_{2} \mathrm{HPO}_{4}, 0.15 \mathrm{~g} ; \mathrm{NaCl}, 0.2 \mathrm{~g} ; \mathrm{MgSO}_{4}-7 \mathrm{H}_{2} \mathrm{O}, 0.2 \mathrm{~g} ; \mathrm{CaCO}_{3}, 2.0 \mathrm{~g} ; \mathrm{FeSO}_{4}$ $0.05 ; \mathrm{Na}_{2} \mathrm{MO}_{4} 0.005 \mathrm{~g} ; \mathrm{NaBO}_{4} 0.005 \mathrm{~g}$ and distilled water 1 liter.

Medium of phosphate dissolving bacteria (PDB):

Nutrient solution $(\mathrm{g} / \mathrm{L})$ : Composed of $\mathrm{K}_{2} \mathrm{SO}_{4} 0.485 ; \mathrm{MgSO}_{4}-7 \mathrm{H}_{2} \mathrm{O}$ $0.200 ; \quad \mathrm{FeCl}_{2}, 0.010 ; \mathrm{CaCl}_{2} \quad 0.376 ; \mathrm{H}_{3} \mathrm{PO}_{4} 0.018 ; \mathrm{ZnSO}_{4}-7 \mathrm{H}_{2} \mathrm{O} 0.0028$ (Shrdeta et al., 1984). All these contents were dissolved in 1 liter water and the $\mathrm{pH}$ of solution was adjusted to $\mathrm{pH} 6.9$ using $\mathrm{KOH}$.

Medium of Potassium dissolving baceria (KDB):

Aleksandrov medium (Hu et al., 2006) Glucose, $5.0 \mathrm{~g}$; magnesium sulphate $\left(\mathrm{MgSO}_{4}-7 \mathrm{H}_{2} \mathrm{O}\right) ; 0.005 \mathrm{~g} ; \mathrm{FeCl}_{3}, 0.1 \mathrm{~g}$; calcium carbonate; $2.0 \mathrm{~g}$; potassium mineral; $2.0 \mathrm{~g}$; calcium phosphate $2.0 \mathrm{~g}$ and distilled water, $1 \mathrm{~L}$.

Compost:

Compost pile was constructed using wastes of rice, cotton and maize by a percentage of $60 \%$ farmyard manure $(35 \%)$ and fertile soil $(5 \%)$. The pile was turned every week and was frequently hydrated with water to be of $60 \%$ moisture.

Wheat grain varieties:

Wheat grain varieties (Egypt 1 and Sed 12 were obtained from Field Crop Institute, Sakha Agriculture Research Station. 


\section{METHODS}

The experiment undertaken in lizemeter composed of 20 unit each of $70 \times 70 \mathrm{~cm} .70 \mathrm{~g}$ of wheat grains were sown in three rows for each lyzemeter unit. The compost amounts were applied according to type of the treatment. Also, the rock phosphate and feldspar ( $400 \mathrm{~kg} / \mathrm{fed}$. for each) were added to biofertilization and organic agriculture treatments. In traditional treatment 15 ppm of $\mathrm{P}_{2} \mathrm{O}_{5}$ and $15 \mathrm{ppm}$ of $\mathrm{K}_{2} \mathrm{O}$ were added as super phosphate and potassium sulphate, respectively. The soil was ploughed and be ready for planting. The wheat grains of biofertilized and organic agriculture treatments were inoculated with mixed inoculum composed of Azospirillum sp., phosphate dissolving bacteria (PDB) and potassium dissolving bacteria (KDB) with the density of about $1 \times 10^{9}$ for each.

The grains of control did not inoculate. The wheat grains Egypt1 and Seds 12 varieties were sown in 3 rows for each lyzemeter unit and irrigated at $60 \%$ of water holding capacity. The treatments were arranged as complete randomized as the following:

1- $100 \%$ NPK (traditional control).

2- Biofertilized plus $50 \% \mathrm{NPK}+400 \mathrm{~g}$ rock phosphate and $400 \mathrm{~g}$ feldspar +2 ton compost/fed.

3- Organic agriculture treatment: biofertilized plus 8 ton compost/fed. $+400 \mathrm{~g}$ rock phosphate $+400 \mathrm{~g}$ feldspar.

Table 1: Some chemical characteristics of the experimental soil

\begin{tabular}{|c|c|c|c|c|c|c|c|c|c|c|c|c|}
\hline \multirow{2}{*}{ EC } & \multirow{2}{*}{ OM\% } & \multirow{2}{*}{\multicolumn{2}{|c|}{\begin{tabular}{|c|c|}
$\mathbf{N}$ & $\mathbf{P}$ \\
\end{tabular}}} & \multirow[t]{2}{*}{$\mathbf{K}$} & \multicolumn{4}{|c|}{ Cations (meq) } & \multicolumn{4}{|c|}{ Anions (meq) } \\
\hline & & & & & $\mathrm{K}^{+}$ & $\mathrm{Na}^{+}$ & $\mathrm{Mg}^{++}$ & $\mathrm{Ca}^{++}$ & $\mathrm{SO}_{4}^{--}$ & $\mathrm{Cl}^{-}$ & $\mathrm{HCO}_{3}$ & $\mathrm{CO}_{3}^{-}$ \\
\hline 2.19 & 1.46 & 103 & 512.82 & \begin{tabular}{l|l|}
2 & 230.7 \\
\end{tabular} & 0.2 & 9.24 & 8.18 & 4.38 & 11.53 & 6.72 & 3.75 & 0 \\
\hline
\end{tabular}

Laboratory experiments of grain infestation:

Laboratory experiments were carried out to study the degree of wheat grain infestation with Rhizopertha dominica.

Insect culture:

Rhizopertha dominica $(\mathrm{F})$ was reared on wheat grains under fluctuating relative humidity $(70 \pm 5 \%)$ and temperature $\left(30+2{ }^{\circ} \mathrm{C}\right)$. New adults emerged ( 7 days old) were used in the next experiments. All experiments were carried out at Department of Stored Product Pests, Plant Protection Research Institute, Sakha Agricultural Research Station.

Susceptibility experiment (non-choice):

During 2013 and 2014 seasons newly harvested wheat grains, Egypt1 and Seds12 varieties, mixing by biofertilizer obtained from biological inoculation with organic agriculture and mineral fertilization treatments were evaluated against infestation with $R$. dominica. Batches of $20 \mathrm{~g}$ grains of all treatments i.e. biofertilization, organic agriculture treatment and conventional agriculture (received $100 \%$ NPK), were placed in small glass jars $(11.5 \mathrm{~cm}$ in height and $6 \mathrm{~cm}$ in diameter). Each jar was infested with 10 unsexed pairs of $R$. dominica 7-day old). Three replicates of each treatment were carried out. The jars were covered with nylon cloth and kept under laboratory conditions.

Observation of the experiment was carried out daily till the 
emergence of adults. At the end of experiment, mean number of adults emerged, weight loss \% and developmental period (life cycle) were recorded. Preferability experiment (Free choice):

To study the preferable of wheat grains, Egypt1 and Seds12 varieties, which obtained from lizemeter experiment, as mentioned before to infestation with $R$. dominica, three separated choice chambers $(60 \times 60 \times 20$ $\mathrm{cm}$ in height) covered with a lid were used as replicates for each treatment. According to the number of treatments, Petri-dishes $(9 \mathrm{~cm}$ diameter) were used, each contain $20 \mathrm{~g}$ of wheat grains and then placed into the jars. Three hundred unsexed adults of $R$. dominica (7-day old) were released in each test chamber to give the insects a free choice to mating and oviposit on any variety. The experiment were conducted at $30+2^{\circ} \mathrm{C}$ and $70+5 \%$ relative humidity.

After the insects were mating and died, they removed then the Petridishes were covered in order to estimate the following parameters at the end of the experiment.

Mean number of emerged adults, mean developmental period (life cycle) and grain weight loss, during 2013 and 2014 planting seasons.

\section{Statistical analysis:}

Data obtained from the two studied seasons was analyzed statistically by the methods of Duncan Multiple range test (Duncan, 1955).

\section{RESULTS AND DISCUSSION}

Two wheat varieties (Egypt1 and Seds12) were fertilized before planting with three types of fertilizers; $100 \%$ NPK (control), mixed biofertilizer $+50 \%$ chemical NPK +2 ton compost $+400 \mathrm{~kg} / \mathrm{fed}$ rock phosphate +400 $\mathrm{kg} / \mathrm{fed}$. feldspar and organic agriculture which biofertilized with mixed inoculum +8 ton compost/fed. $+400 \mathrm{kgf} / \mathrm{ed}$. rock phosphate $+400 \mathrm{~kg} / \mathrm{fed}$. feldspar

The influence of bio-inoculation and organic agriculture systems on weight of 100 grains (grain index) of wheat varied with the variation of the season of planting and the plant variety (Table 2). The variety of Egypt 1 exhibited significant decrease in the weight of 100 grains caused by bioinoculation and organic agriculture systems at both 2013 and 2014 seasons. In respect to Seds12 variety, weight of 100 grains did not show any consistent influence. However, thebioinoculation and the organic agriculture systems caused significant increments for 100 grain weight over the control treatment at the season 2014 only.

Data presented in Table 2 indicated that bioinoculation of wheat grains with the mixed bioinoculant increased grains productivity of Seds 12 wheat variety, while the variety Egypt1 did not significantly influenced. Moreover, organic agriculture treatment (which had no chemical fertilizers nor pesticides) attained positrive significant variation than both traditional chemical fertilized control and bio-inoculated treatment. There was a consistency in data through the two studying seasons, whereas, it attained $268.5 \mathrm{~g}$ wheat grains $/ \mathrm{m}^{2}$ compared to 211.8 for control, at the season 2013 . Similarly, it gave $268.87 \mathrm{~g} / \mathrm{m}^{2}$ compared to 201.2 for control at the season of 
2014. On the other hand, the wheat variety of Egypt1 did not show significant variation as responded by neither bio-inoculation nor organic agriculture treatments. The results of the two seasons had the same trend.

Table 2: Grain index and grains yield $\left(\mathrm{g} / \mathrm{m}^{2}\right)$ of wheat varieties treated with different fertilizers

\begin{tabular}{|l|c|c|c|c|}
\hline \multirow{2}{*}{ Treatment } & \multicolumn{4}{|c|}{ Grain index } \\
\cline { 2 - 5 } & \multicolumn{2}{|c|}{$\mathbf{2 0 1 3}$} & \multicolumn{2}{c|}{$\mathbf{2 0 1 4}$} \\
\cline { 2 - 5 } & Egypt1 & Seds12 & Egypt1 & Seds12 \\
\hline Chemical fert. (NPK) & $6.24 \mathrm{a}$ & $5.74 \mathrm{a}$ & $4.38 \mathrm{a}$ & $3.20 \mathrm{c}$ \\
\hline Bioinoculation & $5.86 \mathrm{~b}$ & $5.00 \mathrm{~b}$ & $4.20 \mathrm{~b}$ & $3.74 \mathrm{~b}$ \\
\hline Organic agriculture & $5.60 \mathrm{~b}$ & $5.16 \mathrm{a}$ & $3.54 \mathrm{c}$ & $4.29 \mathrm{a}$ \\
\hline L.S.D. (0.05) & 0.388 & 0.71 & 0.309 & 0.159 \\
\hline & \multicolumn{4}{|c|}{ Grains yield } \\
\hline Chemical fert. (NPK) & $246.27 \mathrm{a}$ & $211.80 \mathrm{~b}$ & $246.27 \mathrm{a}$ & $201.20 \mathrm{c}$ \\
\hline Bioinoculation & $243.30 \mathrm{a}$ & $219.50 \mathrm{~b}$ & $244.19 \mathrm{a}$ & $219.0 \mathrm{~b}$ \\
\hline Organic agriculture & $232.69 \mathrm{a}$ & $268.50 \mathrm{a}$ & $262.69 \mathrm{a}$ & $268.87 \mathrm{a}$ \\
\hline L.S.D. (0.05) & 63.31 & 33.78 & 25.089 & 16.32 \\
\hline
\end{tabular}

In the same column, for the same parameter, means followed by the same letter are not significantly different at $5 \%$ significance according to Duncan Multiple Range Test.

From the above mentioned results, we must be concluded that, biofertilizers become esthetic and economic needing, they aid for saving chemical fertilizers and help in increasing plant growth. In the present study, the biofertilization treatment saved about $50 \%$ of NPK chemical fertilizers without a negative effect on plant growth of Egypt1 variety, moreover, it attained increases yield of Seds 12 wheat variety. In the same time, organic agriculture treatment saved $100 \%$ of chemical NPK needed and consistently increased plant grain yield.

These results were in accordance with those of Nour El-Din et al. (2011) who found that bio-inoculation of faba bean plants lead to save a big amounts of chemical fertilizers. Inoculation of wheat grain Sakha 93 variety with Azotobacter, Azospirillum and dual of Azotobactrer and Azospirillum can save $20 \mathrm{~kg} \mathrm{~N} / \mathrm{fed}$. compared to chemical fertilizers NPK (Salem, 2008). Moreover, Amara and Dahdoh (1997) stated that, inoculation of wheat with Azotobacter and Azospirillum gave higher grain yield compared to chemical fertilization. On the other hand, Nour El-Din and Talha (2011) reported increases in yield of sugar beet crop without any uses of chemical fertilizers, but substituted by 8 ton compost/fed. and bioinoculation with phosphate dissolving bacteria (PDB) and Azotobacter as well as application of 400 $\mathrm{kg} / \mathrm{fed}$. rock phosphate and feldspars as a source of $\mathrm{P}$ and $\mathrm{K}$.

The addition of well decomposed compost is of important in giving the plant a big part of their nutrient needing, which aid also in improving chemical and physical characteristics of soil as well as enrichment the soil with a lot amount of beneficial microorganisms (Pynk, 1992).

Biofertilizers save huge amount of chemical fertilizers of plant needing according to plant type (from 20 to $70 \%$ ), in addition, biofertilizer 
microorganisms release many substances which improve plant nutrition balance of plants like plant phytohormones, vitamins, organic acids, antibiotics and biocide (Gabr and Nour El-Din, 2012). Weight of 100 grains was noticeable decreased, in the present study due to bio-organofertilization, this may be related to the effect of biofertilization and compost addition on continuous supplementation of nutrients to the plant resulting in increase in flowers fertilizer number and grains formation per spike. The matter which may lead to decrease of grain weight, but increase grain yield. This results agreed with Abd El-Hamid (2002) who noted that number of grains/spike showed positive response to inoculation of nitrogen-fixing bacteria. Additionally, Ali et al. (2003) reported that inoculation of wheat with Azospirillum significantly increased spike number per $\mathrm{m}^{2}$ and grain number per spike.

Laboratory experiments of grain infestation:

In order to study the susceptibility and preferability of wheat varieties mentioned above to infestation with $R$. dominica adults, two laboratory experiments were conducted on the new harvest of grains.

Infestation under non-choice conditions (susceptibility):

Data of Table (3) summarized the degrees of infestation of the wheat grains (Egypt1and Seds12 var.) with R. dominica at seasons 2013 and 2014. Susceptibility was studied through many parameters involved, mean number of adults emerged, mean developmental period (life cycle) and grain weight loss. In respect to Egypt1 variety, bioinoculation treatment revealed significant variation on all studied parameters compared to organic agriculture treatment and chemical fertilization (control) where, it achieved the highest number of adults emerged $(24.67,21.30)$ following by organic agriculture (18.67, 17.67)and chemical fertilization (18.30, 17.0). However, it had the lowest life cycle (40, 41 days) relative to organic agriculture and chemical fertilization which had life cycle as (45, 45 and 45, 45 at seasons 2012 and 2014 , respectively). In addition, the lowest values of grains weight loss \% were recorded with organic agriculture followed by chemical fertilization then bioinoculation treatment with weight loss values recorded 1.5, 1.8 and 2.0; 1.6, 1.8 and 2.0 at seasons 2013 and 2014, respectively. In contrary, for Seds12 variety bioinoculation was the best since it had the lowest number of adults emerged, percent of weight losses and the longest period of life cycle compared to the remained two fertilizer types. They performed $17.3,12.3 ; 43$, 43 and $1.4,1.5$ followed by organic agriculture treatment with values of 18.3 and $13.3 ; 43$ and $4.3 ; 1.4$ and 1.5 then traditional control with values of 22.0 and 20.3; 39 and 39 then 2.0 and 2.0 for adults emerged, life cycle and percent of grains weight loss through season 2013 and 2014, respectively. Results obtained obviously showed that the variety of the plant is a restricted factor in respect to the susceptibility to infestation by $R$. dominica adults where any of the tested fertilizers didn't have the same trend on the tested parameters. 
Table 3: Susceptibility of wheat varieties grains as affected by different fertilizers to infestation by $R$. dominica

\begin{tabular}{|c|c|c|c|c|c|c|}
\hline \multirow{3}{*}{ Treatment } & \multicolumn{6}{|c|}{2013} \\
\hline & \multicolumn{2}{|c|}{$\begin{array}{l}\text { Mean of adults } \\
\text { emerged }\end{array}$} & \multicolumn{2}{|c|}{ Life cycle (days) } & \multicolumn{2}{|c|}{ Weight loss \% } \\
\hline & Egypt1 & Seds12 & Egypt1 & Seds12 & Egypt1 & Seds12 \\
\hline Chemical fert. (NPK) & $18.30 \mathrm{~b}$ & $22.0 \mathrm{a}$ & $45.0 \mathrm{a}$ & $39.0 \mathrm{~b}$ & 1.8 & 2.0 \\
\hline Bioinoculation & $24.67 \mathrm{a}$ & $17.3 \mathrm{~b}$ & $40.0 \mathrm{~b}$ & $43.0 \mathrm{a}$ & 2.0 & 1.4 \\
\hline Organic agriculture & $18.67 \mathrm{~b}$ & $18.3 \mathrm{~b}$ & $45.0 \mathrm{a}$ & $43.0 \mathrm{a}$ & 1.5 & 1.4 \\
\hline \multirow[t]{2}{*}{ L.S.D. $(0.05)$} & 1.15 & 1.27 & 1.054 & 0.667 & - & - \\
\hline & \multicolumn{6}{|c|}{2014} \\
\hline Chemical fert. (NPK) & $17.00 \mathrm{~b}$ & $20.3 a$ & $45.0 \mathrm{a}$ & $39.0 \mathrm{~b}$ & 1.8 & 2.0 \\
\hline Bioinoculation & $21.30 \mathrm{a}$ & $12.3 \mathrm{~b}$ & $41.0 \mathrm{~b}$ & $43.0 \mathrm{a}$ & 2.0 & 1.5 \\
\hline Organic agriculture & $17.67 \mathrm{~b}$ & $13.3 \mathrm{~b}$ & $45.0 \mathrm{a}$ & $43.0 \mathrm{a}$ & 1.6 & 1.5 \\
\hline L.S.D. $(0.05)$ & 1.74 & 1.46 & 0.471 & 0.667 & - & - \\
\hline
\end{tabular}

In the same column, for the same parameter, means followed by the same letter are not significantly different at $5 \%$ significance according to Duncan Multiple Range Test.

Infestation under free choice conditions (Preferability)

The same parameters of mean number of adults emerged, mean developmental period (life cycle) and grains weight loss $\%$ were estimated to investigate susceptibility of wheat grains using free-choice method (preferability) which allowed the insects to mate and oviposite on any treatment. It is worthy to conclude that the results of preferability experiment had the same trend of susceptibility experiments (Table 4) at the two studied seasons. Bioinoculation treatment had undesirable effects for grains of the Egypt1 variety which had the highest number of adults emerged as (15.3, 14.67)as well a shorter life cycle with $(40,39)$ and highest values of grain weight loss as $(1.4,1.4)$ at seasons 2013 and 2014, respectively. While, the same fertilizer manifested acceptable influence on grains of Seds12 var. lowest number of adults emerged longest life cycle and lowest values of grain weight loss for the all tested parameters at both seasons. Therefore, it must be reported that wheat grains of Seds12 variety, resulted from bioinoculation and organic agriculture systems were considered moderate tolerant to $R$. dominica attack post treatment. These results were confirmed by several researchers, whereas Michael et al. (2000) concluded that cultivars which harboring a large number of $R$. dominica progeny were considered more susceptible than those of fewer progeny number. Gharib (2004) reported that varieties with high values of Sitotroga cereallela progeny with shorter life cycle were considered susceptible, in contrast varieties which had the lowest number of progeny and longer life cycle were considered least susceptible. 
Table 4: Preferability of wheat grains varieties as affected by different fertilizers to infestation by $R$. dominica

\begin{tabular}{|c|c|c|c|c|c|c|}
\hline \multirow{3}{*}{ Treatment } & \multicolumn{6}{|c|}{2013} \\
\hline & \multicolumn{2}{|c|}{$\begin{array}{l}\text { Mean of adults } \\
\text { emerged }\end{array}$} & \multicolumn{2}{|c|}{ Life cycle (days) } & \multicolumn{2}{|c|}{ Weight loss \% } \\
\hline & Egypt1 & Seds12 & Egypt1 & Seds12 & Egypt1 & Seds12 \\
\hline Chemical fert. (NPK) & $9.0 \mathrm{c}$ & $14.67 \mathrm{a}$ & $45 a$ & $39 \mathrm{~b}$ & 1.0 & 1.8 \\
\hline Bioinoculation & $15.3 \mathrm{a}$ & $9.00 \mathrm{~b}$ & $40 \mathrm{~b}$ & $44.3 \mathrm{a}$ & 1.4 & 0.93 \\
\hline Organic agriculture & $11.0 \mathrm{~b}$ & $9.67 \mathrm{~b}$ & $45 \mathrm{a}$ & $43 \mathrm{~b}$ & 1.0 & 1.0 \\
\hline \multirow{2}{*}{ L.S.D. $(0.05)$} & 1.56 & 1.54 & 1.045 & 0.667 & - & - \\
\hline & \multicolumn{6}{|c|}{2014} \\
\hline Chemical fert. (NPK) & $7.0 \mathrm{c}$ & $12.7 \mathrm{a}$ & $45 \mathrm{a}$ & $39 \mathrm{~b}$ & 1.0 & 1.80 \\
\hline Bioinoculation & $14.67 \mathrm{a}$ & $6.67 \mathrm{~b}$ & $39 \mathrm{~b}$ & $44 \mathrm{a}$ & 1.4 & 0.80 \\
\hline Organic agriculture & $9.67 \mathrm{~b}$ & $5.0 \mathrm{c}$ & $45 \mathrm{a}$ & $44 \mathrm{a}$ & 1.0 & 0.83 \\
\hline L.S.D. (0.05) & 1.87 & 1.61 & 0.471 & 0.471 & - & - \\
\hline
\end{tabular}

In the same column, for the same parameter, means followed by the same letter are not significantly different at $5 \%$ significance according to Duncan Multiple Range Test.

Shafique et al. (2006) reported that, wheat variety which exhibited higher number of adults emerged and weight loss $\%$ considered susceptible to insect infestation and variety which had lowest number of adults emerged and minimum weight loss considered resistance to insect pests. In this respect, Adetunji (1988) concluded that, mean adults emerged could be used as indirect measure of non-performance, as well as developmental period was significantly longer in resistance than susceptible varieties. Therefore, the lowest number of adult emerged and longest developmental period (life cycle) proved clear evidence of non-preference. This evidence indicated that wheat grains of Seds12 variety is considered tolerant to insect attack post storage where it exhibited significant decrease of mean adults emerged, grain weight loss and the longest life cycle compared to traditional control. Also, the present findings agreed with Salem (2008). She reported that, wheat grains of Sakha93 variety exhibited significant decrease of total larval emerged, total adults emerged, grain weight loss and had the longest life cycle of Trogoderma granarium under single and dual bacterial inoculation of Azotobacter and Azospirillum. Moreover, Zain and Abo Arab (2000) reported that wheat variety Sakha8 and Sakha92 fertilized with Azotobacter and/or farmyard manure caused significant detrimental effect on the number of progeny of $R$. dominica and Sitophilus oryzae.

It could be concluded that, wheat grain resistance to storage insects is a complex phenomenon which can be attributed to various physiochemical characteristics of grains, insect species and abiotic factors (Ahmed and Ahmed, 2002).

From the above mentioned results, it can be concluded that wheat grain treated with bacterial inoculation and agriculture treatment exhibited moderate tolerance to insect attack post harvest especially with grains of Seds 12 variety at the two experimental seasons. This tolerance may be due to some variations in chemical composition of grains which might be due to bacterial inoculation or organic farming treatment. Biofertilizers keep the rhizosphere soil rich in all kinds of macro and micronutrients via nitrogen 
fixation, phosphate and potassium solubilization or mineralization as well as release of plant growth regulating substances (Sinha et al., 2014). When biofertilizers were applied as seed or soil inoculants, they multiply and participate in nutrient cycling and benefit crop productivity.

In this regard, chemical analysis of wheat grains Sakha93 treated with single and dual inoculation of Azotobacter and Azospirillum exhibited significant increases of $\mathrm{N}, \mathrm{P}, \mathrm{K}$ macro and micronutrients, total carbohydrates, total protein and chlorophyll content (Salem, 2008). These results were supported by several research which confirmed changes in chemical composition as a result of bacterial inoculation. Fayez et al. (1985), Warembourg et al. (1987) reported that $\mathrm{N}$ content significantly increased in wheat shoots and seeds under Azospirillum inoculation. El-Hawary et al. (1998) concluded that NPK content in wheat grains and straw significantly increased when inoculated with Azospirillum strains. Inoculation of wheat with a mixture of Azotobacter + Azospirillum significantly increased NPK and micronutrient content (Amara and Dahdoh, 1997). Moreover, Cheremisov and Red-Kina (1984) reported that inoculation of wheat with Azospirillum strains increased grain protein content. In this context, chemical analysis of faba bean seeds, Sakha 1 variety exhibited significant increases in $N, P, K$, micronutrient and total protein due to inoculation with Rhizobium and Azotobacter (Abo Arab et al., 2008).

It is worthy to conclude that the use of bacterial inoculation (biofertilizers) and organic agriculture treatment (biofertilizer with addition of organic fertilization but not have any pesticides) may be altered the chemical composition of wheat grains, therefore, the difference in susceptibility of wheat grains to insect infestation may be due to a change in chemical composition which produced grains less susceptible or moderately tolerant. On the other hand, bacterial inoculation exhibited some susceptible with Egypt1 variety and this results may be due to the kind of wheat variety.

Finally, the current results reported that any of the tested fertilizers did not achieve the same effect on both varieties, so this study recommend the use of additional amount of compost for Egypt1 variety with the bioinoculation treatment, where the yield potentiality of this variety was higher than those of Seds12.Also no doubt that the use of biofertilization will minimize the pollution arising from mineral fertilizers or chemical pesticides.

\section{REFERENCES}

Abd El-Ghany, B.F. (1994). Effect of biofertilization and chemical fertilizers on soil microbial properties and fodder production under calcareous soil conditions. Desert Inst. Bull., Egypt, 44(2): 247-262.

Abd El-Hamid, I.M. (2002). Effect of some agronomic practices on wheat. Ph.D. Thesis, Fac. Agric., Zagazig Univ., Egypt.

Abo Arab, R.B.; H.M. El-Zun andAbeer A. Salem (2008). Effect of biochemical fertilization on physiological properties and insect infestation of faba bean seeds in storage. Egypt. J. Agric. Res., 86(2): 785-802. 
Adesemoye, A.O. and J.W. Kloepper (2009). Plant microbes interaction in enhanced fertilizer-use efficiency. Appl. Microbial Biotechnol., 58:921-929.

Adetunji, J.F. (1988). A study of the resistance of some sorghum seed cultivars to Sitophilus oryzae (L.) (Coleoptera : Curculionidae). J. Stored Product. Res. 25(2): 67-71.

Ahmed, M. and A. Ahmed (2002). Storage of food grains. Farm. Outl., 1: 1620.

Ali, O.; O. Caglar and F. Sahin (2003). Yield response of wheat and barley to inoculation of plant growth promoting rhizobacrteria at various levels of nitrogen fertilization. Journal of Plant Nutrition and Soils Science, 166(2): 262-266.

Amara, Mervat, A.T. and M.S.A. Dahdoh (1997). Effect of inoculation with plant growth promoting rhizobacteria (PGPR) on yield and uptake of nutrients by wheat grown on sandy soils. Egypt. J. Soil Sci., 37, No. 4, pp.467-484.

Bato, S.M. and F.F. Sanchez (1972). The biology and chemical control of Callosobruchus maculatus (L.). Phillip. Ent. 2: 169-182.

Biswase, R.; M. Basu; A. Sen-Majumdar and M. Bas (1985). Biochemistry. 24: 3795-3802.

Cheremisov, B.M. and T.V. Red-kina (1984). Effectiveness of Azospirillum inoculation of wheat in the non-chernozem zone. Dpkladg, Vsesoyuznoi Ordena Lenina-1-Ordena Trudovogo Krasnogo Znameni Akademii Sel Skokhozy aistvennykh Nauk Imeni Vi Lenina 10: 15-16.

Duncan, D.B. (1955). Multiple Range and Multiple F-test, Biometrics, 11: 142.

El-Banby, M.A.; A.A. Selim; M.S. El-Zemaity and S.I. Salama (1985). The inter-relationship between infestation with some bruchid beetles and their requirements of certain chemical components in leguminous seeds. Bull. Soc. Ent., Egypt. Ecol. Ser. 14, (263).

El-Hawary, Fatma; I.I. Ibrahim, and F. Hammouda (1998). Effect of integrated bacterial fertilization on yield and yield components of wheat in sandy soil. J. Agric. Sci. Mansoura Univ., 2(5): 1951-2057.

El-Kased, F.A.; R.N. Kamh and F. Abd El-Ghany (1996). Wheat response to bio and mineral nitrogen fertilized in newly reclaimed sandy soil. Desert Inst. Bull., Egypt., 49(2): 373-386.

Fayez, J.M.; N.F. Eman and H.E. Makboul (1985). The possible use of nitrogen fixing Azospirillum as biofertilizers for plants. Egypt. J. Microbiol., 20(2): 190-206.

Gabr, M.A. and M. Nour El-Din (2012). Evaluation of selected Azospirillum $s p$. isolates on improving growth, yield and fruit quality of anna apple trees. J. Agric. Chem. and Biotechn., Mansoura Univ., 3(3): 65-75.

Garib, M.S.A. (2004). Susceptibility of some wheat grain varieties to Sitotroga cerealella infestation. Egypt. J. Agric. Res., 82(4). 
Hu, X.F; J. Chem and J.F. Guo.(2006).Two phosphate and potassium solubilizing becteria isolated from Tianna Mountain , Zehejiang , china. World j. Micro. Biotech., 22:983-990.

Irshad, M.; W.A. Gillani and A. Khan (1988). Maize grain resistance to Sitotroga cerealella and Sitophilus oryzae. Pakistan J. Agric. Res., 9:539-542.

Katyal, J.C.; B. Venkatashawrlu and S.K. Das (1994). Biofertilizers for nutrient supplementation in dry land agriculture. Fertilizer News, 39(4): 27-32.

Koura, A.; M. El-Halafawy and W. Darkal (1971). Preference of the cowpea weevil Callosobruchus maculatus to some legume seeds and weight loss due to insect infestations. Agric. Res. Rev., Cairo, 49: 35-40.

Micheal, D.T.; G.W. Cuperus and T.W. Phillips (2000). Susceptibility of eight U.S. wheat cultivars to infestation by Rhizopertha dominica (Coleoptera: Bostrichidae). Bio one online Journal Access Control., Vol. 29, issue 2, Environmental Entomology Article, pp. 250-255.

Nour El-Din, M. and N.T. Talha (2011). Impact of long-term application of chemical biological and organic fertilizers on some soil characteristics and sugar beet productivity. N. Egypt. J. Microbiol. Vol 30., September, 2011.

Nour El-Din, M.; A.R. El-Shanshoury and I.A. El-Akhdar (2011). Isolation and evaluation of salt-tolerant microorganisms and their impact in adaptation of faba bean to salinity stress. J. Soil Sci. and Agric. Eng., Mansoura Univ., 2(9): 977-999.

Pynk, P. (1992). On farm composting handbook Northeast Regional Agricultural Engineering Service, 152 Riley-Robb Hall, Ithaca, NY 14853-5701.

Salem, A.A. (2008). Effect of biofertilization and chemical fertilization on physiological properties and infestation of wheat and faba bean plants in field and during seed storage. Ph.D. Thesis, Fac. Science, Al-Azhar Univ., Egypt.

Shafiqu, M.; M. Ahmed and C.M. Ashraf (2006). Evaluation of wheat varieties for resistance to Angoumois grain Moth., Sitotroga cerealella (Olivier) (Lepidoptera: Gelechiidae). Pakistan Journal of Zoology, 38(1): Jhang Road, B. Faisalabad.

Shrdeta, V.; A. Gaudinova; M. Necova and A. Hyrakova (1984). Behaviour of nodulated Pisum sativum L. under short term nitrate stress conditions. Biol. Plant., 26: 384.

Sinha, R.K.; D. Valani; K. Chauhan and S. Agarwal (2014). Embarking on second green revolution for sustainable agriculture by vermiculature bio-technology using earthworms: reviving the dreams of Sir Charles Darwin. Int. J. Agric. Health Saf, 1: 50-64.

Vancura, V. and J. Mucura (1960). Indol derivatives in Azotobacter cultures. Folia Microbial., 5: 293. 
Wani, S.P. and K.K. Lee (1995). Microorganisms as biological inputs for sustainable agriculture in organic agriculture (Thapmpan, P.K. ed.). Peekay Tree Crops Development Foundation, Cochin, India, pp. 39-76.

Warchalewski, R.; D. Piasecka-Kwiatkowska; J. Nawrot and Z. Winiecki (1993). Natural protection system of cereal grain against storage pests-myth or fact? Ochrona-Roslin, 37: 10, 11-12.

Warembourg, F.R.; Dreessen; Vlassak and F. Lafont (1987). Peculiar effect of Azospirillum inoculation on growth and nitrogen balance of winter wheat Triticum aestivum. Biology and Fertility of Soils, 4(12): 55-59.

Zain, F.L. and R.B. Abo Arab (2000). Combined effect of bio-organofertilization at different $\mathrm{N}$-levels on the degree of insect infestation by Sitophilus oryzae L. and Rhizopertha dominica F. J. Agric. Sci. Mansoura Univ., 25(7): 4637-4645.

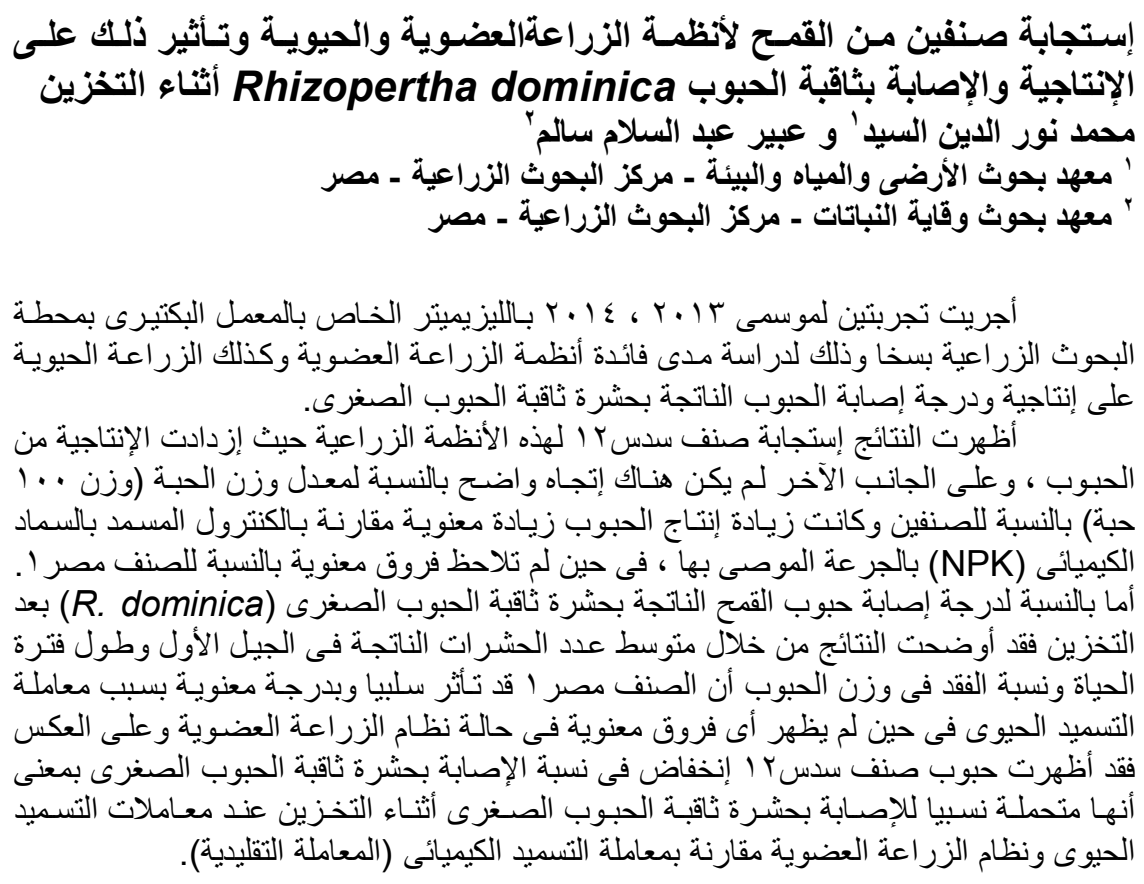

